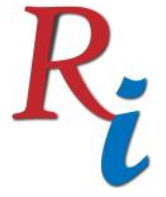

Asia Proceedings of Social Sciences

(APSS)

www.readersinsight.net/APSS

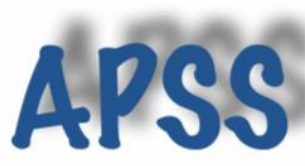

\title{
AN OVERVIEW OF THE IMPACT OF RESTRUCTURING ON \\ Public Service in Nigeria
}

Aminu Mohammed Lawan*

School of Social Sciences

Universiti Sains Malaysia

Malaysia

Department of Political Science

Yobe State University, Damaturu.

Nigeria

Razlini Mohd Ramli

School of Social Sciences

Universiti Sains Malaysia

Malaysia

\section{Siti Zuliha Razali}

School of Social Sciences

Universiti Sains Malaysia

Malaysia

*Corrosponding author's Email: aminuhadi2@gmail.com

Peer-review under responsibility of $3^{\text {rd }}$ Asia International Multidisciplanry Conference 2019 editorial board

(http://www.utm.my/asia/our-team/)

(C) 2019 Published by Readers Insight Publisher,

lat 306 Savoy Residencia, Block 3 F11/1,44000 Islamabad. Pakistan,

info@readersinsight.net

This is an open access article under the CC BY-NC-ND license (http://creativecommons.org/licenses/by-nc-nd/4.0/). 


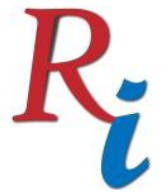

\section{Asia Proceedings of Social Sciences \\ (APSS) \\ www.readersinsight.net/APSS}

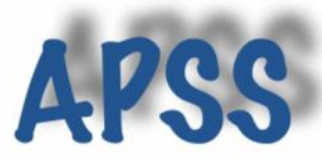

\section{Rese a r ch H igh I ight s}

The restructuring of public service in Nigeria commenced in the 1970s a few years after independence by the military regime, with the main reason for reducing the redundancy and get rid of corruption from the system. The action does away with several thousand civil servants in that period on the ground of inefficiency and indiscipline. On the return to civilian rule in 1999, the democratic regime of Obasanjo introduce the restructuring of public service, because of the following reasons; erosion of work ethics, ageing labour force, poor planning, unsuitable organisational structures, fruitless labour processes, incompetent headship, etc. This paper highlight the problem of public service in Nigeria that warrant government execute the restructuring to ensure quality service delivery. This reorganisation impact on public sector employees notably reduced their social security and other welfare services.

\section{Graphic a I A bstract}

Globalization is the increasing interaction of peoples, states or countries through the growth of the global trade, international flow of capital, ideas and culture. The paper discusses how privatization of public corporations and invention of information and communication technology (ICT) lead to the retrenchment and casualization of public servant. The aim of this study is to examines the impact of globalization on the public servant in Nigeria. The methodology involves the use of secondary data, through a systematic literature review which entails the document analysis of related matters. The findings reveal that globalization infringes on the right of a public servant by making them vulnerable without job security. The paper concludes that government must stop unfair labor practice such as retrenchment and casualization of workers, and improve good working conditions to make public servant more productive.

Keywords: Restructuring, Nigeria, Public Service, Employees

\section{Research Objectives}

This study aims and objectives is to examine the impact of restructuring on public service in Nigeria.

\section{Methodology}

The methodology involves a systematic literature review which entails the document analysis of secondary data of the related subject matter.

\section{Results}

Appah and Appiah (2010) maintain that incidents of the scam are widespread in the civil service in Nigeria that all section of the administrative works, might appear to be implicated in one system or the another in a number of these cruel shams. The annoyance of civil service financial misconduct in Nigeria then the crude oil prosperous times a phase in which there was physically fragile check instrument, which generates a diversity of ambiguities that have inclined to enable and endure, immoral habits. These problems necessitate the structural reform of the public sector in line with the current global best practice (Eriamiantoe, 2014).

The highlighting motive for transformation in the public service is the pursuit to convey around enhancement in both the procedures and excellence service conveyance. Any determination focused at work upgrading either in relations to equipping, tools, providing of necessary 


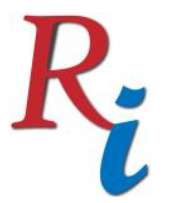

\section{Asia Proceedings of Social Sciences \\ (APSS) \\ www.readersinsight.net/APSS}

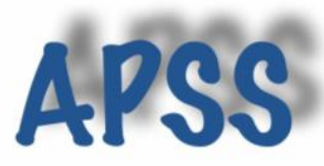

amenities and the rise of pleasant attitude and behaviour frame could be designated as a reform inventiveness (Magbadelo, 2016).

The Civil Service reorganisation executed at three (3) categories; the overall worker's examination and personnel rationalisation; Organizations, Divisions and subdivisions transformation built on improvement; and converge all-embracing transformations. Change at divisional level involved at the preliminary stage, ten Ministries. These departments are, moreover, at different stages of execution. The reshuffle was steered with the help of two broad Rules: first for Departments and the second for Parastatals. The whole struggle on track with authentication and substantiation of staff strength on the workforce supposedly to eradicate ghost workers and generate the acute reference point data for directing successive labour force breakdown (Eme \& Ugwu, 2011).

The World Bank's Wage and accomplishment scheme in Sierra Leone employed political economy synthesis to advance a problematic public service modification plan that undertook diplomatically suitable reorganisations and applied them systematically and cooperatively through the inventive usage of a goal-oriented capital measure that permitted for continual elasticity (Srivastava \& Larizza, 2013).

The public service had been declining with an overextended federal spending summary over the years. Persistent shortfalls funded by internal and foreign borrowing with subsequent high debt service load, collapse of the old apparatuses of regulator leading to fraud and embezzlement of resources, prevalence of ghost employees, deprived appraisal of programs and plans, a vast collection of deserted/current projects particularly in well-organized and inefficient parastatal (Aduke, 2007). The inconsistency contains here in the fact that Organizational and Economic Restructuring in the civil service has been subject to the terrible condition of public funds resultant from the economic recession of 2008. This medium was mainly an outcome of the banking crunch. As the crisis also endangered the survival of many currencies, the state of national assets advanced of improved significance at international level and many statutory creativities reinforced global authority in this setting. Civil service reform is not a new miracle for several nations of the globe. (Ehiyamen, 2017).

\section{Findings}

The study findings reveal that public service restructuring was carried out by the government of Nigeria to ensure quality service delivery. However, it is also linked to the neoliberal agenda of an international financial institution as part of the conditionality of debt pardon in developing countries. It also synthesises the social, commercial and governmental reorganisations of public service by Obasanjo's regime which determination is made to encourage progressive state in Nigeria. The paper concludes that major approaches followed by the Nigerian government to reform the civil service have not been able to realise its anticipated results fundamentally because of partisan, historical, fiscal, institutional, social and further ecological restrictions.

\section{References}

Brinkerhoff, D. W., \& Brinkerhoff, J. M. (2015). Public sector management reform in developing countries: Perspectives beyond NPM orthodoxy. Public Administration and Development, 35(4), 222-237.

Ehiyamen, O. (2017). Administrative and Financial Reforms in the Nigerian Public Sector. Journal of Public Administration, Finance and Law(11), 37-48. 


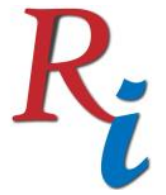

\section{Asia Proceedings of Social Sciences}

(APSS)

www.readersinsight.net/APSS

Eme, O. I., \& Ugwu, S. C. (2011). Developmental state bureaucracy in Nigeria: restructuring for effectiveness (1999-2007). Arabian Journal of Business and Management Review, 1(4), 44-54.

Eriamiantoe, O. I., Albert Felix. (2014). Due Process as an Instrument for Public Accountability: A Case Study of Ministry of Finance and Budget., $(2,1)$. Uniben Press Limited.

Magbadelo, J. O. (2016). Reforming Nigeria's federal civil service: Problems and prospects. India Quarterly, 72(1), 75-92.

Srivastava, V., \& Larizza, M. (2013). Working with the grain for reforming the public service: A live example from Sierra Leone. International Review of Administrative Sciences, 79(3), 458-485.

$\mathrm{Xu}, \mathrm{G}$., \& Wu, Y. (2016). Basic public services and the restructuring of the public finance system in China: Retrospect and prospect. Asian Education and Development Studies, 5(4), 438-453. 